\title{
Aristoteles'in Dört Neden Kuramının Çeviribilim Alanındaki Kuramsal Yaklaşımlara Etkisi ${ }^{1}$
}

\author{
Muharrem Tosun (D), Sakarya - Nesrin Şevik (D), Karaman
}

https://dx.doi.org/10.37583/diyalog.802263

$\ddot{O}_{z}$

Felsefenin ve dolayısıyla düşünce tarihinin en önemli filozoflarından biri olan ve başta mantık, fizik, metafizik, astronomi, siyaset, retorik olmak üzere birçok alanda eserler veren Aristoteles'in (M.Ö. 384322) bu eserlerde bildirdiği görüşleri birçok disiplinin kendi kuramlarını oluşturmasında büyük önem arz etmektedir. Onun özellikle bir şeyin varlı̆̆a gelişini açıklamada kullandığı Dört Neden Kuramı, şeyin gerçek bilgisine ulaşmada yol göstericidir. Bugüne değin varlığın bilgisine ulaşma, olguların açıklanması söz konusu olduğunda birçok bilim dalı Dört Neden Kuramından yararlanmıştır. Yirminci yüzyılın son çeyreğinde bir bilim dalı olma çabası içerisine giren çeviribilimin disiplinlerarası bir bilim dalı olup olmadığ 1 son on yıllarda sorgulanmaya başlanmıştır. Fakat yapılan çalışmalarda varılan sonuçlara bakıldığında ortak bir görüş birliğinin olmadığı görülmektedir. Çeviri olgusu bugüne kadar, çeviribilimin ilgili olduğu dilbilim, kültürbilim, metinbilim, iletişimbilim, yorumbilim, edebiyatbilim, sosyoloji, felsefe gibi birçok disiplinin biri veya birkaçının verileri ile açıklanmaya çalışılmış ve hala daha da açıklanmaya çalışılmaktadır. Bu açıklamalara sıklıkla maruz kalan kaynak/erek metin, kaynak metin yazarı/çevirmen ve çevirinin amacı gibi öğeler felsefi bir perspektiften ele alındığında temelde nedensel bir sorgulama gerektirmektedir. Felsefe tarihine bakıldığında ise varlığa ilişkin yapılan nedensel sorgulamanın, temelde Aristoteles'in Dört Neden Kuramına dayandığı görülür. Bu çalışmada betimleyici bir yaklaşım izlenerek ilgili öğeler disiplinlerarası bağlamda genelde Aristoteles'in görüşleri, özelde ise onun özellikle Metafizik ve Fizik eserlerinde konu ettiği Dört Neden Kuramı ile ele alını irdelenecek ve bu kuramın çeviri olgusuna nasıl bir ışık tuttuğu izaha çalışılacaktır.

Anahtar Sözcükler: Aristoteles, çeviribilim, amaç, erekbilim, Dört Neden Kuramı.

\section{Abstract \\ The Effect of Aristotle's Four-Cause Theory on the Theoretical Approaches in the Field of Translation Studies}

Being one of the most significant philosophers of the philosophy and thereby the history of thought; and having written works on many fields such as primarily logic, physic, metaphysic, astronomy, politics, rhetoric Aristotle's (384-322 B.C.) thoughts pointed out in these works have a great importance in lots of disciplines constructing their own theories. The four-cause theory he uses in explanation of an entity getting into existence, is a guiding light to reaching the exact knowledge of the entity. Up to the present, when reaching the knowledge of the existence and explanation of the facts come into question, various branches of science have benefited from the four-cause theory. In the last decades, it has been questioned whether translation studies, which has attempted to become a branch of science in the last quarter of the

\footnotetext{
${ }^{1}$ Bu makale 2016 yılında danışmanlığını Prof. Dr. Muharrem Tosun'un yaptı̆̆ı “Çeviribilimde Skopos Kuramının Felsefi Bakış Açısıyla Yeniden Yorumlanması” adlı doktora tezinden üretilmiştir.

Einsendedatum: 17.07.2020

Freigabe zur Veröffentlichung: 30.09.2020
} 
twentieth century, is an interdisciplinary branch of science or not. However, when the results deduced from the studies are examined it is seen that there is not a common consensus. The translation phenomenon has been tried to be explained with the data of one or more of a whole range of disciplines such as linguistics, cultural science, text science, communication science, interpretation, literature science, sociology, philosophy; and is still tried to be explained more. When the factors such as source / target text, source copywriter / translator and the purpose of the translation, frequently exposed to these explanations, are discussed within the philosophical perspective, it is seen they fundamentally require a causal inquiry. Looking at the history of philosophy, it is seen, that the causal inquiry on existence is basically based on Aristotle's Four-Cause Theory. In this study, by following a descriptive approach, the relevant elements will be examined with the views of Aristotle in general in an interdisciplinary context, and particularly with the Four-Cause Theory, which he has mentioned in his works of metaphysics and physics, and it will be tried to explained how this theory sheds light on the phenomenon of translation.

Keywords: Aristotle, Translation Studies, Target, Teleology, Four-Cause Theory. 


\section{EXTENDED ABSTRACT}

It is necessary to benefit from the essential concepts and theories of these disciplines in the explanation and definition of some phenomena in the translation studies, as various disciplines effect the translation, the translation process and the translator. Towards the end of the 1970s, with the help of the fact that the language and culture in which the translation is made took primacy, the target of translation, and the translator subject making the translation, the act of the subject etc. became a research topic separately. It is due to the nature of translation that the phenomenon of translation and the factors that affect this phenomenon are discussed and explained within the context of quite different disciplines. When the translation is mentioned the source text, the target text, the translator and the aim of the translation come into the mind firstly; and it is not possible for the translation to come into existence without one of these four elements. When these four elements are asked to be questioned on the basis of philosophy, it is necessary to consider the reasons of these elements' coming into existence, and the explanation of the causal thinking in the field of philosophy is based on Aristotle's theory of four causes. In this theory of Aristotle, purpose constitutes one of the four main types of cause with matter, form and agent together. The four-cause theory Aristotle has obtained as a result of his effort to access knowledge is needed when it is desired to reach the knowledge of an entity. The exact explanation of an entity is possible by explaining the cause for its existence, that is, its purpose, together with the material, formal and agent causes. In his Works entitled Physic, Metaphysic and Posterior Analytics Aristotle expands on the four-cause theory. Aristotle, who tries to explain the four causes over bronze sculpture, within the context of this object explains them by identifying the material cause with the bronze with which the sculpture is made, the formal cause with the shape of it, the efficient cause with the person who makes it, and finally the final cause with the goal of its getting made. As a result of this example it is possible to summarize the material cause as a base, formal cause as an essence, efficient cause as an entity from whom/which the variance arises and final cause as the purpose of the entity's getting into existence. As it is not possible for any of these causes alone to explain the existence of an entity, it is necessary to take four of them together into consideration in the explanation of existence.

If the existence of translation is aimed to be questioned and explained within the context of Aristotle's four-cause theory, it is fairly necessary to discuss source text as part of the material cause, target text as part of formal cause, the translator as part of efficient cause and the target of the translation as part of final cause. In Aristotle's fourcause theory the matter is the one accepting the change and in this respect it is the producer of the thing. In the context of translation studies, it is possible to say that this is the source text which equals to it with regards to the abovementioned factors. In the motion from the source text that is potential to the target text which is virtual, the completion of the movement, namely the motion, occurs with the help of the existence of the target text, the virtual, arising from the source text, the potential. The target text does not come into existence on its own; and as it is an entity to be sensed, it is an object connected to the source text in terms of being existent. One of the four causes, 
the formal cause is a cause meaning the act of coming into existence from an entity and it is possible to say the final cause equals to this type of cause in the context of the translation studies. The target text is evolved into the target text throughout the translation process, and the target text becomes an edited, meaningful and formed type of the source text, which is found in an irregular form in the target world. In four-cause theory, when an efficient cause is the matter, the cause which is the source of a movement and change is meant. The equivalent of this type of cause in translation studies is the translator as the agent.

The translator, who makes the act of translation from the source text, presents a production, nominately the target text. On the other hand, the final cause, discussed as the last type of the causes, makes explanations on the purpose of the existence of an entity. Therefore; the final cause is the end which is aimed to be reached when an action is done. Within the framework of translation studies, it can be said this type of cause is equivalent with the purpose of translation. Since the act of translation is a purposeful activity, it gives an opportunity to it to direct the translation process. An explanation within the context of the efficient cause will reveal why the translation is made.

In the studies on translation, it is possible to come across with the Works of Anthony Pym and Andrew Chesterman on Aristotle's four-cause theory and translation based on these causes. Just like in Pym and Chestermann's Works, in this study the existence of translation will be attempted to be based on Aristotle's four-cause theory as well. After each cause type has been explained in general terms, how these types of causes have been discussed in the translation studies until today will be discussed, and then the equivalent of each cause in the translation studies will be tried to be found out and the causal questioning of the equivalents will be tried to be made. These inquiries will not merely be made on the basis of Aristotle's four-cause theory, but his views on motion and change will be included in the inquiries too. 


\section{Giriş}

Diller, kültürler, toplumlar arasında gerçekleşen çeviri etkinliği, bu özelliğinden ötürü geniş bir konu ve alan yelpazesine sahiptir. Bu da çeviribilimin diğer disiplinlerle bir arada ya da yan yana bulunmasını gerektirir. Aristoteles'e göre (2010: 191) şeyler ortak bir kavrama sahip olabilir ve bu şeylerin incelenmesi tek bir bilimin alanına ait değildir. İkinci Çözümlemeler (2011: 28) kitabında bilimlerin alan ve konu bakımından birbirlerini kapsadığına değinen Aristoteles, optiğin geometriye bağlı olması gibi başka bir bilimin de optiğe bağlı olabileceğinden bahseder ve yay biçimli yaraların daha yavaş iyileştiğini bilmenin hekimin iş, nedenini bilmenin ise geometricinin işi olduğu örneği ile bilimler arasındaki ilişkiyi izaha çalışır. Tıpkı bu örnekte olduğu gibi çeviri ne sadece metinsel ve iletişimsel ne de dilbilimsel bir etkinliktir. Çevirinin birçok disiplin ile varlığa gelmesi, her bir çeviri durumunda birden fazla disiplinin bir arada bulunmasına, fakat bunlar arasında en az bir disiplinin baskın olmasına olanak sağlar. Dolayısıyla alan ve konu bakımından birden fazla disiplinle dirsek temasında olan çeviribilim kendi kuram, yöntem, terminoloji ve hatta araştırma nesnesini, farklı bilimlerin ilkelerinden yararlanarak açıklamaya çalışır, bu disiplinlerden biri de felsefedir.

Varlı̆̆ın ve bilginin bilimsel olarak araştırılması ${ }^{2}$ anlamına gelen felsefenin, birçok disiplinin kendisine dayanan yöntemler kullanarak varlığını izaha çalışmasında temel bir disiplin olduğu söylenebilir. Felsefe tarihine baktığımızda Sokrates, Platon, Aristoteles gibi filozofların, yaşadıkları dönemde dile getirdikleri görüşlerinin hala daha birçok alanda etkin ve etkili olduğu görülmektedir. Bu alanlardan biri de Çeviribilimdir. Çeviribilim alanında 80'li yıllarda ortaya çıkan işlevsel ve betimleyici kuramların ortak yönü temelde erek odaklı kuramlar olmalarıdır ve bu kuramlar Aristoteles'in dört nedeninden biri olan ereksel nedende yoğunlaşmaktadır. Özellikle Skopos Kuramında erek odaklı anlayış ve çevirinin skoposu, yani ereği, kuramın Aristoteles'in Dört Neden Kuramı çerçevesinde sorgulanmasına olanak sağlamaktadır.

Çeviribilimde paradigma değişiminin öncülerinden olan Skopos Kuramı (1984) ve Çeviri Eylemi Kuramı (1984) çevirinin hedefi ve amaçlanan işlevi üzerine inşa edilmelerinden ötürü Aristoteles'in nedensellik anlayışı çerçevesinde bu kuramlara yönlendirilecek çeviri neden o şekildedir? sorusuna verecekleri en olası cevap çevirinin amacından ötürü olacaktır. Bir eylemin nedeni göz önünde bulundurulmak istendiğinde nedenler hakkında düşünmek kaçınılmazdır, nedenler üzerine düşünme ve nedensel bir açıklama söz konusu olduğunda bunun felsefe alanındaki izahı Aristoteles'in Dört Neden Kuramına dayanır. Bu kuramda madde, form ve fail nedenle birlikte ereksel neden, dört temel neden türünden birini teşkil etmektedir.

Tümdengelimli bir yol haritasının izlendiği bu çalışmada öncelikle Aristoteles'in Dört Neden Kuramı genel hatları ile izah edildikten sonra bu kuramın Anthony Pym ve Andrew Chesterman tarafından çeviribilimde nasıl ele alındığına değinilecektir. Son aşamada ise Dört Neden Kuramı temelinde çeviri süreci ve çevirmen kararları açısından çeviride değişen unsur olarak kaynak metin, çevirinin yönü olarak erek metin, çevirinin

\footnotetext{
${ }^{2}$ TDK, https://sozluk.gov.tr; 29.06.2020
} 
faili olarak çevirmen öznesi ve çevirinin amacı olarak çeviri eyleminin amacı irdelenecektir.

\section{Aristoteles ve Dört Neden Kuramı}

Bir nesne hakkında ne içini kavramadığımız sürece o nesneyi bilemeyeceğimizi söyleyen Aristoteles'e göre bir şeyi bilmek ancak o şeyin nedenlerini bilmekle mümkün olur ve bir şey ancak dört neden ile varlık kazanır (Aristoteles 1997: 61,81; 2010: 8789). Aristoteles Dört Neden Kuramına özellikle Metafizik 1. Kitap (A) 3. bölümde ve Fizik eserinde oldukça geniş yer vermiştir.

- Maddi Neden (hyle): Her değişme ve oluş gerçekleşmek adına bir dayanağa, bir özneye ihtiyaç duyar ki bu da madde dediğimiz şeydir. Bir şeyin yapılmasında veya meydana gelmesinde veya meydana gelen şeyde oluşturucu unsur olarak bulunan ve bu bakımdan bir şeyin varlığa gelmesinde temel rol oynayan madde, kendisine bir değişme yüklenen ve ilgili değişmeyi kabul etme özelliğine sahip olandır, yani taşıyıcı öznedir. Örneğin $s u$ hem soğuma hem de ısınma niteliğini kabul eden ama onlardan bağımsız olarak var olan bir şeydir. Madde hem doğal olayların olmasında hem de sanat eserlerinin meydana getirilmesinde önemli bir rol oynar. Örneğin bir heykeltıraşın bir heykel yapmak için mermere ihtiyacının olması ve bu mermerin heykel olabilme özelliğine sahip olması gerekmektedir. Dolayısıyla sanat eserlerinin meydana getirilmesinde madde oluşturucu bir unsur olarak karşımıza çıkar. Madde değişmeyi kabul edendir, bir şeyi o şey yapan, onu meydana getirendir, bir anlamda dayanaktır (Arslan 2007: 174f).

- Formel Neden (eidos): Nedenlerle bilmede maddi neden tek başına yeterli değildir. Maddi neden maddenin değişmeyi kabul ettiği süreçte değişme sonucunda her zaman için bir şey başka bir şey olur ve bu başka şeyi Aristoteles form olarak adlandırır. Madde olmadan var olamayan ve değişim sonucunda ortaya çıkan form, hareketsiz ve değişmez olandır. Bir şeyden meydana gelmiş olmak bakımından formel neden, varlığa ne olduğuna dair yönelteceğimiz sorunun cevabını verir ve bu bakımdan varlığın tanımının yapılmasında yardımcı olur. Madde dayanak iken, form özdür, çünkü her şeyin niçin’i, sonuçta onun tanımına indirgenmektedir (Aristoteles 2010: 87f).

- Fail Neden (kinoun): Fail neden değişmenin, durağanlığın, sükûnetin, hareketin kaynağıdır. Baba çocuğun, meşe tohumu meşe ağacının, heykeltıraş heykelin fail nedenidir. $\mathrm{Bu}$ neden türünde söz konusu olan yapanın yapılan şeye, değiştirenin değişime uğrayan şeye, hareket ettirenin hareket edene etkide bulunmasıdır (Aristoteles 2010: 236; Böyüközkara 2010: 11). Sadece oluş ve yok oluş söz konusu olduğunda araştırılan fail neden, değişmenin kendisinden ileri geldiği şeydir (Aristoteles 2010: 372f).

- Ereksel Neden (telos): Her türlü oluş ve değişmenin ereği olarak ereksel nedeni gören Aristoteles'e göre ereksel neden bir şeyin ne için olduğunu açıklayan 
neden türüdür (2010: 89). Metafizik eserinin II. Kitabının ikinci bölümünde ereksel nedenin bir erek olduğunu ifade eden Aristoteles, ereksel nedenin bir başka şeyi elde etmek için istenen türden bir erek olmadığını; tersine onun, başka her şeyin kendisi için istendiği türden bir erek olduğunu ve insanın her zaman bir ereğe ulaşmak için eylemde bulunduğunu belirtir (Aristoteles 2010: 150). Yine Metafizik eserinin ikinci kitabının ikinci bölümünde erek veya amacın bir eylemin sonu olduğunu belirten Aristoteles ereğin, diğer şeylerin kendisinden dolayı bir neden olduğunu ve her eylemin bir hareketle birlikte bulunduğunu belirtir (2010: 157).

Gözler görmek için, dişler koparmak ve ögütmek için, kollar tutmak için yapılmış veya düzenlenmiş görünmektedirler. İnsandan hemen her zaman insan, meşe tohumundan yine hemen hemen her zaman meşe ağacı meydana gelmektedir. Rastlantısal sonuçlar ne her zaman ne de çoğunlukla karşımıza çıkmaktadır. O halde gözlemlenen bu uyumlar ne rastlantının, ne de kör bir zorunluluğun sonuçları olamazlar. Tek seçenek onların bir amaç için oldukları ve doğanın bir bütün olarak bir amaca veya ereğe göre her şeyi düzenlediğidir (Arslan 2007: 181).

Aristoteles'e göre bir ve aynı şey bu dört nedeni kendisinde toplayabilir ve ona göre sanat veya mimar bir evin fail nedeni iken, toprak ve taşlar o evin maddesi, evin yerine getirdiği işlev o evin ereksel nedeni, evin tanımı ise o evin formel nedenidir (2010: 158).

\section{Dört Neden Kuramı ve Çeviribilim}

Aristoteles'in görüşleri felsefeden sanata, siyasetten tıbba kadar birçok bilime etki etmiştir. Çeviribilim alanında ise birçok yeni yaklaşım ve anlayışın ortaya çıktığı 80'li yıllarda Anthony Pym, çeviribilimin kuramsal yapısının sorgulanmasında Aristoteles'in Dört Neden Kuramını konu edinmiş ve daha sonra aynı yaklaşım 90'lı yıllarda Andrew Chesterman tarafından yeniden ele alınmıştır.

\section{Anthony Pym ve Dört Neden Kuramı}

Anthony Pym, Method in Translations History (1988) ve On Translator Ethics (2012) eserlerinde Aristoteles'in Dört Neden Kuramı ve Skopos Kuramına değinmiştir.

Pym ilk baskısını 1988 yılında çıkardığı Method in Translation History adlı eserinde Aristoteles'in Dört Neden Kuramını ve bunun çeviribilime uygulanabilirliğini şu şekilde değerlendirmiştir;

- Maddi Neden: Çeviri eylemine yön veren ve çevirinin başarısı için gerekli olan (varsayılan) kaynak metin, dil, iletişim teknolojisi vb. her şey maddi ya da ilk neden olarak adlandırılabilecek olan bu neden altında ele alınabilir. 
- Ereksel Neden: Ereksel neden çevirinin varlığını gerekçelendiren amaçtır ve erek kültür içerisinde ya konumsal bir işlev ya da bir eylemin ideal olarak tamamlanması şeklinde izah edilebilir.

- Formel Neden: Formel neden normlar bağlamında ele alınabilir. Müşteri, alıcılar, çevirmen, diğer çevirmenler, kısacası bir çeviriyi kabul eden kişiler kim olursa olsun, çevirinin çeviri olarak kabul edilmesini sağlayan tarihsel normlar vardır ve bu normlar formel neden sinıfina girmektedir.

- Fail Neden: Fail neden çevirmen öznesidir (Pym 2014: 149).

Pym (2014: 149) Aristoteles'in bu dört nedeninden maddi nedeni metinleri üretmek için ihtiyaç duyulan kaynak metin, ereksel nedeni tamamlanmış çevirinin bir amaç için üretilmesi, yani üretilen metnin amac1, formel nedeni çevirinin kabul görmesini sağlayan normlar ve fail nedeni çeviri eylemini gerçekleştiren çevirmen öznesinin varlığı olarak değerlendirmektedir ve bu nedenler aracıllı̆ıyla çeviriye dair gerekliliklerin ortaya koyulduğu görüşündedir. Bu nedenlerden herhangi birinin göz ardı edilmesi sonucunda çevirinin de söz konusu olamayacağını söyleyen Pym için bu dört neden, bir çevirinin var olabilmesi adına gereklidir ve birinin olmayışı, çeviri olgusuna bütünsel bir yaklaşıma engel olacaktır. Dolayısıyla bu nedenlerden en az biri baskın olmak kaydıyla hangi ya da hangilerinin baskın olması gerektiğine dair herhangi bir zorunluluk yoktur. Nedenlerin tümü gerekli olmakla beraber, tek bir neden çevirinin bütününü kapsayarak çevirinin nedeni olarak görülmez.

Pym, çeviride maddi neden söz konusu olduğunda kaynak metne, kaynak dile ve erek dile bakılması gerektiğini belirtir ve bu aşmada erek dili, tıpkı heykeltıraşın heykelini yaptığı mermere benzetir ve bu bakımdan erek dili ham bir madde olarak ele alır. Ona göre maddi neden çevirinin gerekli ama yetersiz koşuludur ve çeviri olgusu üzerine fazla bir bilgi veremez. Ereksel neden söz konusu olduğunda çevirinin amacının, yani skoposunun söz konusu olduğuna değinen Pym'e göre amaç, çevirinin erek tarafındaki belirli bir yer ve zamanda, belirli insanlar açısından bir işlev yerine getirmek zorunda olunan şeydir. Fail neden söz konusu olduğunda ise çevirmeni öne çıkaran Pym, çevirmeni etiği gerçekleştiren özne olarak tanımlar. Formel neden ise Pym'e göre çeviriye ait biçimdir (2014: 150-156).

Pym Aristoteles'in Dört Neden Kuramının günümüz çeviri kuramlarının büyük ihtiyaç içinde olduğu toplumsal dinamiklere bir örnek teşkil edip edemeyeceği sorusuyla yüzleşir ve ilk baskısını 2012 yılında çıkardığı On Translator Ethics adlı kitabında dört nedeni yeniden ele alır (2012: 89).

- Maddi Neden: Çevirmen tarafından kullanılan kaynak metin, sözlükler, veri tabanları, çeviri bellekleri gibi farklı etmenlerdir.

- Ereksel Neden: Çeviri işinin gerekçesidir, yani çeviri metnin gerekçelendirilmesidir. Dolayısıyla bir ereksellik söz konusudur ve bu neden ile çevirilerin erek kültürde nasıl bir işlev gördüklerine dair amaç analizi yapılabilir. 
- Formel Neden: $\mathrm{Bu}$ neden türü söz konusu olduğunda akla gelen yaratıcı eylemin çeviriye olan etkisidir. Çeviriyi kabul edilir kılan şey, çevirinin formu ve tarihsel normlardir.

- Fail Neden: Fail neden çevirmen öznesi ve öznenin bir eylemde bulunmasından dolayı da çevirmen etiğidir. Çevirmenler çeviriyi birileri onlara söylediği için veya toplumsal koşullar gerektirdiği için değil de doğru olanı yapmayı seçtikleri için çeviri eyleminde bulunurlar (Pym 2012: 89).

İleride de görüleceği gibi Chesterman'ın nedenler açıklamasında kendine yer bulamayan kaynak metnin Pym'ın açıklamalarında ele alındığı görülmektedir. Başta maddi neden olmak üzere diğer nedenlerin ele alınıp değerlendirilmesinde Pym'in yaklaşımının Aristoteles'e daha yakın olduğu söylenebilir.

Pym, Reiss/Vermeer tarafından 1984 yılında yayınlanan Grundlegung einer allgemeinen Translationstheorie adlı eserde ortaya koyulan Skopos Kuramının çeviride amacı ve işlevi öncelemesi bakımından, kuramın Aristoteles'in nedenler öğretisiyle ele alınıp inceleneceği görüşündedir. Ereksel neden amacın (skopos) ne olduğunu açıklamamakta, sadece diğer her şeyin amaçtan doğduğu anlamına gelmektedir. Bu neden türü Skopos kuramının temelini oluşturmasına rağmen Vermeer ve Mäntäri’nin çevirmen öznesini öne çıkartmaları ve böylece çevirmen tutumunu önceleyerek çeviri eylemini çevirmen kararı olarak görmelerinden ötürü, ereksel neden fail neden karşısında zayıf kalmaktadır (Pym 2012: 93f).

\section{Andrew Chesterman ve Dört Neden Kuramı}

Çeviribilimde erekbilimsel bir açıklama yapılmak istendiğinde bu açıklamaların kendine dayanak alacağı ilk kuramın Skopos Kuramı olduğunu belirten Andrewe Chesterman On Explanation (2008) adlı makalesinde Aristoteles ve onun Dört Neden Kuramına yer vermiştir.

Chesterman bu çalışmasında varlıkları açıklamanın dört temel yolu olarak da bilinen Aristoteles' in dört nedenini çeviribilime uygulamaya çalışmıştır;

- Maddi Neden: Erek metindeki ifade biçiminin mevcut halde olmasının nedenini metnin oluşumunun maddi nedeni olarak değerlendiren Chesterman, çevirilerin farklı araçlar dahil olmak üzere "soyut dil malzemelerinden" yapıldığını dile getirir. Çeviriler hedef dilde oluşturulurlar ve bu nedenle "neden bu çeviri böyle?" sorusunun cevabı "dilin doğasından dolayı, hedef dilden dolayı ve hedef ve kaynak dil arasındaki ilişkiden dolayı”dır. Dolayısıyla Chesterman'a göre bunun gibi nedensel bir açıklama, eşdeğerlik temelli çeviri kuramlarına işaret etmektedir. Bu ise metin düzeyli çeviri kuramlarında geçerli olmakta ve korpus temelli çalışmalara vurgu yapmaktadır (Chesterman 2008: 370f).

- Ereksel Neden: Çevirmenin erek metin oluşumunda kullandığı ifade biçiminin mevcut halde olmasının nedeni öznenin, yani çevirmen failinin onu üretmekteki amacıdır. Çevirideki ifade biçiminin mevcut halde olmasının nedeni amaçtan 
ötürüdür. Chesterman nedenselliğin erekbilimsel bir açıklama olduğunu söyler ve erekbilimsel açıklamaların uygulanabileceği kuramların başında Skopos Kuramının geldiğini belirtir. Fakat çevirinin hedefini veya amaçlanan işlevini öne çıkarması ve bunların çevirmen kararları ve eğitimi için temel prensip olarak ele alınması gerektiğini öncelemesinden dolayı kuramın daha ziyade buyurucu olduğu görüşündedir.

- Formel Neden: Formel neden çevirideki ifade biçimidir. Çevirideki ifadelerin mevcut halde olmasının nedeni, çeviriden beklenen formel gereklilikten ötürüdür. Diğer bir deyişle, nedeni normlardır. Çeviri söz konusu olduğunda bu normlar öncelikle erek kültüre aittir. Hatta daha genel olarak ilgili çeviri geleneğine de ait olduklarını söylemek mümkündür.

- Fail Neden: Fail neden çevirideki ifade şekli ile ilişkilidir. Bu neden türü çevirmen öznesinin fiziksel ve zihinsel durumu ile yakından ilintilidir. Fiziksel ve zihinsel durum ile kastedilen, çevirmenin beden ve zihnidir (2008: 371).

Chesterman'ın dört nedeni sadece erek metin ve çevirmen üzerinden değerlendirdiğini söylemek yanlış olmaz. Fakat bir şeyin bilinmesi, onun nedenleri ile bilinmesini gerektirdiğinden, çeviri açısından bir nedensel sorgulama yapıldığında, varlığın, yani erek metnin nedenine ulaşmak için kaynak metnin bu sorgulamada özellikle maddi neden bağlamında değerlendirilmesi gerekmektedir.

$\mathrm{Bu}$ çalışmasından iki yıl sonra yayınlanan Skopos Theory: a Retrospective Assessment (2010) adlı çalışmasında yeniden Dört Neden Kuramına değinir ve çevirinin niçin böyle olduğunun sorusuna verilecek olan cevabın onun skoposu olduğunu söyler. Skopos'u Aristoteles'in ereksel nedenine anlamsal olarak yakın bulduğunu ama kuramın bu ereksel nedeni diğer nedenlere oranla abarttığına yönelik tartışmaların olduğunu dile getirir. Yine aynı çalışmada formel nedeni erek kültür normları olarak sınıflandıran Chesterman, Skopos kuramının bu nedeni de dikkate aldığını belirtmekte, fakat fail ve maddi nedeni çok fazla önemsemesinden dolayı eleştirmektedir. Çevirmenin aklı ve vücudunu, hatta bilgisayarları bile fail neden kategorisinde değerlendiren Chesterman, bir önceki dört neden sınıflamasında her ne kadar maddi neden değerlendirmesinde kaynak metne değinmemişse de bu çalışmasında maddi neden denildiğinde erek dil kısıtlamalarının yanı sıra kaynak metni de dikkate almıştır (Chesterman 2010).

\section{Aristoteles'in Dört Neden Kuramı ve Çeviribilim}

Bir şey hakkında bilgi sahibi olmak, yani bir şeyi bilmek, ancak o şeyin nedenini bilmek veya onu nedeniyle bilmekle mümkündür ve nedensel düşünmenin felsefe alanındaki izahı Aristoteles'in maddi, fail, formel ve ereksel olarak adlandırdığı Dört Neden Kuramına dayanır. Bu dört neden, bir şeyin o şey olmasını açıklayan, yani bir varlığın ancak nedenlerini bildiğimizde onu bilebileceğimizi gösteren nedenlerdir. Aristoteles'in bu yaklaşımından yola çıkarak çeviri denen etkinlikte bu dört nedenin nasıl uygulanabileceği, nasıl ele alınabileceği gösterilmeye çalışılacaktır. Dört nedenin neler 
olduğuna dair bilgi ve açıklamalara yukarıda yer verildiğinden burada nedenlerin çeviribilim çerçevesinde nasıl tezahür edebileceğine değinilecektir.

\section{- Maddi Neden ve Çeviribilim}

Aristoteles'e göre görünür gerçeklikler var olmak adına iki şeye ihtiyaç duyar, bunlar bir şeyin ne olduğunu bilmemizde rol oynayan madde ve formdur. Aristoteles her türlü belirlemenin dayanağı olarak maddeyi görür ve maddi nedene göre her şeyin bir niçini olduğunu ve bu niçin sorusunun cevabının onun tanımına indirgeneceğini söyler (2010: 87). Madde ancak form aracılığıyla bir gerçeklik kazanmakta ve varlık halini almaktadır ve bu bakımdan madde kendi halinde var olabilirken, form hiçbir zaman kendi başına var olamamaktadır. Formun var olabilmesi bir değişimi gerektirmektedir ve değişim denilen şey maddenin, bir formu terk edip başka bir form almasıdır (Arslan 2007: 141,143). Tıpkı işlevsel çeviri kuramlarında da kendine sıkça yer bulan, bir kaynak metnin erek kültürde birden fazla farklı çevirisinin olması bu bakımdan açıklayıcıdır, yani kaynak metnin bir erek metin formundan başka bir erek metin formunu alması şeklinde açıklanabilir.

Çeviribilim çerçevesinde Dört Neden Kuramı ele alınmak istendiğinde çevrilecek metin (Berk 2005: 133), çevirinin yapılacă̆l metin (Delisle, Lee-Jahnke, Cormier 1999: 340) olarak tanımlanan kaynak metnin maddeye karşılık gelebileceği söylenebilir. Çeviribilim terminolojisinde madde olan kaynak metin, bir anlamda güç halinde erek metindir ve bu bakımdan erek metin, kaynak metin aracılığıyla meydana gelen, onun vasıtasıyla gerçekleşen bir formdur. Dolayısıyla kaynak metin madde olmak bakımından önce gelendir ve form olan erek metin maddeden hareket eden ve bir amacı bulunandır. Kaynak metnin erek dünyada yönelmiş olduğu gaye olan erek metin, erek dünyada esas olandır. Kaynak metnin, erek metin dünyasında pasif durumda olması, etken hale gelebilmek için erek metnin varlığına ihtiyaç duymasını gerekli kılar ve bu bakımdan erek metin formuna geçer.

Çeviri sürecinde biri çevirmen ve erek metin olmak üzere aktif, diğeri kaynak metin yazarı ve kaynak metin olmak üzere pasif iki faktör bulunmaktadır. Bunlar birbirlerinden ayrı olmakla beraber birbirleriyle bağlantılı öğelerdir. Çeviribilimsel bakış açısında çevirmen öznesinin etkide bulunan, kaynak metin nesnesinin ise etkiye maruz kalan olduğu görüşü yaygınken, aslında tersi bir durumun söz konusu edilmesi olasıdır. Dört Neden Kuramı bağlamında bir değerlendirilme yapılmak istendiğinde çeviri sürecine etkide bulunan ve etkin olanın kaynak metin ve kaynak metin yazarı olduğu söylenebilir. Nitekim bir çeviri durumundan ve de bir erek durumdan bahsetmeyi olanaklı kılan, kaynak metnin ve buna bağlı olarak kaynak metin yazarının varlığıdır. Çeviriyi mevcut bir kaynak metinle bağlantılı olarak işlev odaklı bir erek metin üretimi olarak gören Christiane Nord, çeviride kaynak metnin ve kaynak metin yazarının varlığının bir anlamda önemine vurgu yapmaktadır (2011: 17). Nord'un çeviriyi kaynak metinden başlayan bir etkinlik olarak görmesi, onun kaynak metin yazarına karşı sadakat kavramını ortaya koymasına olanak sağlamıştır (Salevsky 2002: 201). 
Çeviri süreci denilen eylemsel etkinlikte, çevirme yeteneğine sahip olan bir sanatkârın kaynak metin denilen maddeyi, diğer bir dil ve kültüre aktarması söz konusudur. Dolayısıyla çeviri, sanatkârının müdahalesiyle gerçekleşen bir etkinliktir ve bu etkinlik sonucunda ortaya çıkan erek metin, kaynak metin dolayısıyla varlığa gelendir. Nitekim Skopos Kuramında kuramcılar çevirmenin önceden var olan bir metinle çalıştığını belirtmektedir (Reiss/ Vermeer 1984: 19). Erek metnin, kendisinden önce var olan kaynak metnin varlığı aracılığıyla meydana gelmesi yahut kaynak metnin madde olmak bakımından varlığı, kaynak metin ve erek metin arasında bir öncelik sonralık ve buna bağlı olarak da neden-etki durumunun söz konusu edilmesine imkân tanır. Erek metnin nedeni kaynak metin iken, kaynak metnin etkisi ise erek metindir. Erek metin olmadan önce de var olan kaynak metin gerek erek metin oluşurken gerekse de oluştuktan sonra, madde olmak bakımından varlığını sürdürmeye devam eder. Varlığını kaynak metinden alan erek metin ise kaynak metin var olduğu için vardır. Kaynak metnin bir formu olan erek metin, kaynak metinden bağımsız olarak tanımlanamazken, kaynak metnin kendisi metin olarak tanımlanabilmek adına erek metne ihtiyaç duymaz.

Bir metne kaynak metin denilmesi, erek metnin varlığı veya varlık olasılığı söz konusu olduğu içindir. Aksi takdirde o, herhangi bir dilde yazılmış herhangi bir metindir. Kaynak metnin erek dünyada varlığa gelmesi söz konusu olduğunda, metin kaynak metin adını alır ve tanımı yapılır. Kaynak metin tek bir dilde var olmasına karşın, birçok dilde, hatta aynı dilde bile birden fazla çeviriye sahiptir. Birçok dilde erek metnin var olması, varlığını tek bir dilde yazılmış olan kaynak metne borçludur. Hangi metnin çevrileceği bilinmese de herhangi bir metnin çevrileceği mutlaktır. Bu bakımdan var olan nesne (kaynak metin), oluşmayan nesnenin (erek metin), oluş nedeni olarak o nesneden daha önce devinen bir nesne olarak vardır.

Görüldüğü üzere çeviribilimde önce gelen konumundaki kaynak metnin doğası gereği gerek zaman gerekse de hareket bakımından önce gelmesi, onun bilgiye sahip olması bakımından da önce geldiğini gösterir, yani kaynak metin bir bilgi taşıyıcısıdır ve Vermeer'in deyimiyle bilgi sunumu olan kaynak metin, erek metinden önce gelerek onun oluşumunu sağlayandır. Skopos kuramına göre çeviri işleminin yönünün erek metin tarafından belirlenmesi, erek metinin varlığı ile ilgili sorgulamalara bir anlamda zemin hazırlar. Çünkü ortada henüz bir erek metin yoktur, sadece söz konusu olan olası bir metnin varlığından bahsedilmektedir. Olmuş olan üzerinden olacak olanın amacı ne derecede ondan ayrı olabilir? sorgulanmalıdır.

$\mathrm{Bu}$ açıdan Nord'un bir anlamda kaynak metin ve erek metin ile ilgi hesaplaşmada bulunduğu Textanalyse und Übersetzen (2003) adlı eserinde çevirinin gerçekleşebilmesi için var olan kaynak metnin durumu ile varlığa gelecek olan erek metnin durumu arasındaki uyumluluğa ek olarak kaynak metnin amacı ve erek metnin işlevi arasında bir uyumluluktan bahseder. Yani çeviri bir anlamda çevirinin amacının kaynak metinle olan uyumluluğuna bağlıdır.

Bir kaynak metinden erek metin dışında bir şey çıkmayacağı da açık olmakla beraber, aynı kaynak metinden bir maddeden çeşitli formların üretilmesi gibi farklı erek 
metinlerin çıkması söz konusudur, bu farklı erek metinlerin maddesi aynı olmakla beraber form olma özellikleri birbirinden farklıdır. Madde olan kaynak metin her yeni form almada, yani her çevrilişinde formla, yani erek metinle yeni bir ilişki kurar. Dolayısıyla Tosun'un da belirttiği gibi (2013: 45f) her bir çeviri, erek metnin kaynak metinle yeniden kurduğu bir ilişkidir. Yani her bir form, töz ve dayanak arasındaki bir ilişki sonucunda meydana gelir.

\section{- Formel Neden ve Çeviribilim}

Aristoteles'in Dört Neden Kuramından biri olan formel neden bir şeyden meydana gelmek bakımından nedendir. Formel neden maddi nedeni kendine dayanak olarak alan, öz anlamında bir neden türüdür (Aristoteles 2010: 87f). Maddi neden ve formel neden için biri dayanak biri öz olmak bakımından birbirinden ayrılamayacak olan iki neden türü denebilir (Aristoteles 2010: 237). Bir önceki neden türünün kaynak metne karş1lık gelebileceği savının yer alması, bu neden türünün de maddi neden olan kaynak metni dayanak almasından dolayı erek metin ile karşılanmasını mümkün kılar. Çeviribilim terminolojisinde çeviri metin, başka deyişle çeviri sürecinin ortaya çıkardı̆̆g metin (Berk 2005: 120; Delisle, Lee-Jahnke, Cormier 1999: 416) olarak tanımlanan erek metin, bu tanımlamadan da anlaşılacağı üzere bir şeyden hareket eden ve bir süreç sonucunda ortaya çıkan bir metindir. Çevirinin hareket noktası olan kaynak metin (Nord 2003: 104) potansiyel olarak çeviri formlarına gebedir ve erek metnin maddesi konumundadır. Bu anlamda tüm çeviriler bir anlamda kaynak metnin birer formudur.

Çeviribilimde formel nedene her ne kadar ilk değerlendirmede erek metin karşılık gelse de formel nedeni kendi içerisinde sınıflandırmanın ve bu nedene etki eden diğer faktörleri sıralamanın mümkün olduğu görülmektedir. Zira çeviribilimde;

1) kaynak metnin formu

2) erek metnin formu

olmak üzere iki çeşit formdan bahsedilebilir.

Kaynak metin, yazarının zihinsel tasarımı sonucu varlığa gelirken, erek metin kendi formunu, çevirmen aracılığı ile kaynak metin üzerinden elde etmektedir. Bu bakımdan erek metin, kaynak metnin erek dünyadaki formudur ve form olmak bakımından kaynak metni kendisine madde olarak dayanak alır. Öznenin düşünce ve yeteneğine bağlı olarak varlığa gelen erek metin, çevirmen öznesinin amaçlı ve planlı eylemi sonucu meydana gelir.

Erek metin çevrileceği dil, okunacağ rastlantısal bir metin değildir, bilakis bir amacı yerine getirmek için form alan bir metindir. Yaratıcı düşünme etkinliğine sahip olan bir öznenin planlı davranışının bir ürünü olan bir amaç temelinde üretilip bir hedefe ulaşma ilkesine sahip olan genel anlamda metinler, özelde kaynak ve erek metin, temelde bir insan etkinliğinin ürünü olarak meydana gelmiştir. 
Skopos kuramına göre çevirinin çıkış noktası A dilinde yazılmış olan bir metindir ve bu metin Z dilindeki alıcılar için Z diline aktarılır (Vermeer 1983: 48; Nord 2003: 27). Bir amaç doğrultusunda gerçekleşen çeviri, A noktasında başlayıp B noktasında biten bir süreçte gerçekleşen bir etkinlik olarak ele alındığında bu iki nokta arasında geçen süreçte, metni hareket ettiren, metne etki eden başta kaynak dünya (kaynak dil/yazar/kültür/alıcı vd.) olmak üzere iş veren, çevirmen, erek dünya (erek dil/kültür/alıcı vd.) gibi birden fazla etken vardır. B noktasına varıldığında çeviri süreci sona ermekte, hedeflenen değişim tamamlanmakta, hareket son bulmakta ve nihayetinde devinim gerçekleşmiş olmaktadır. Devinim sonucunda ortaya çıkan metin artık erek dünyada, erek dil ve kültürdedir. Dolayısıyla erek metin, var olabilmek adına devinimine kaynak metinden başlayan ama adını devindiği erek dünyadan alan bir formdur.

Aristoteles'in Fizik ve Metafizik eserlerinde oldukça geniş yer bulan değişim, doğası gereği kalkış ve varış noktası, zihin durumu ve bununla bağlantılı bir zaman dilimini içerir. Değişim potansiyel olandan aktüel olana doğru gerçekleştiğinden, varlığa gelecek olan şey aktüel olarak var olmadan önce, varlığını şeyin kendisinde potansiyel olarak zorunlu kılar (Aristoteles 2010: 73; Ross 2002: 103). Bu bakimdan erek metin olma potansiyelini kendinde barındıran kaynak metin için şunu söylemek mümkündür; kaynak metin erek dil ve kültüre çevrilene dek erek dünyada mutlak anlamda değil, olanak halinde yoktur. Olanak halinde var olmak demek bir şeyde etkinlik haline geçmeden önce var olmak demektir (Özcan 2011: 20,29). Madde olarak var olmak fakat form kazanmak bakımından bir yoksunluğa sahip olmak, yani henüz bir gerçeklik kazanmamış olmak demektir. Erek metin aracılığı ile erek dünyada etkinlik halinde var olacak olan kaynak metin algılanabilmek için onu algılayan özneye ve özne tarafından algılanacak nesne olan erek metne ihtiyaç duyar. Nesne olmak bakımından erek metnin, kendisini algılayıp yorumlayacak bir öznenin varlığını gerekli kılması, bu nesnenin ancak onu yorumlayan özne ile varlığa geldiğini gösterir.

Çevirmenin çeviri süreci ile, kaynak metin yazarının metin üretme süreci, birbirinden farklı ve bireysel olan iki ayrı an'dır. Çevirmen, kaynak metin yazarının kendi bireysel an'ında ürettiği kaynak metni alır ve durağan bir durumdan devingen bir duruma dönüştürür. Bu dönüşümde çevirmenin eylemi bir durumu değiştirmeye yönelik olması bakımından bir karar verme sürecini de beraberinde getirir. Eylemlerin bir karar verme süreci olarak bir amaca yönelik olması, var olan bir durumdan, olacak olan bir duruma ulaşmaya olanak sağlar (Vermeer 1986: 219f). Bu da;

1. var olanın var olageldiği, yani kaynak metin yazarı tarafından üretildiği zaman, yani geçmiş zaman,

2. çevirmenin bu metni ele aldığı şimdiki zaman ve

3. metnin bittiği gelecek zaman,

olmak üzere üç zaman diliminden söz edilmesini gerektirir.

Eylemler olacak olana yönelik olmaları bakımından geleceğe yöneliktirler ve amaç odaklıdırlar. Çeviri denilen ve bir özne tarafından gerçekleştirilen eylemler de bu 
bakımdan amaçlı eylemlerdir ve bu amaçlı eylemler bir sonuca, yeni bir duruma ve hatta yeni nesneye yöneliktir (Vermeer 1990: 72). Amaçlı eylem sonucunda bir ürün olarak erek dünyada yer alan erek metin formuna form veren, kaynak metin maddesinin dışında çevirmenin dil ve kültür bilgisi, dünya görüşü, alıcının beklentileri, sosyal konumu, erek dilin olanakları, vb. etkenler de erek metnin form almasında belirleyici unsurlardır ve çeviri ürününün alacağı nihai biçimi belirlemede etkindirler.

Kaynak metinden türeyen, ondan meydana gelen, ondan var olan bir metinden bahsedilebilmesi için bu metnin nesne olmak ve tanımlanabilmek bakımından bir isme sahip olmasını gerektirir ve değişim sonunda değiştiği dünyada aldığ isim erek metin'dir. Bir erek metin, erek kültür, erek dil, erek alıcı vb. terimler kaynak metin, kaynak dil, kaynak kültür, kaynak alıcı terimlerinden ötürüdür ve tersi durumun da söz konusu olduğuna maddi neden bölümünde değinilmiştir.

Çeviribilimde bilhassa Skopos Kuramı ile öne çıkan erek metin, kaynak metin bilgi sunumu üzerinden bir bilgi sunumudur ve çevirinin amacına ulaşması, onun işlevsel olmasına ve alımlayıcısı tarafından kabulüne bağlıdır.

\section{- Fail Neden ve Çeviribilim}

Aristoteles' in Dört Neden Kuramında fail neden bir hareketin, değişmenin kaynağı olan nedendir. $\mathrm{Bu}$ nedende yapanın yapılan şeye, değiştirenin değişime uğrayana, hareket ettirenin hareket edene etkide bulunması söz konusudur (Büyüközkara 2010: 11) Aristoteles' in nedenlerinin çeviribilimde karşılıkları bulunmak istendiğinde fail nedenin çevirmen öznesi ile karşılanabileceğini söylemek mümkündür. Delisle, Lee-Jahnke ve Cormier'in eserinde yazılı çeviri yapan ve sözlü çeviri yapan olarak ayrı ayrı ele alınan çevirmen öznesi, yazılı çevirmen başlığ altında Yazılı belgeleri bir dilden diğerine aktaran iletişim uzmanı şeklinde tanımlanmıştır (1999: 350, 401). Berk tarafından Bir metni bir dilden başka bir dile çeviren kültürlerarası iletişim uzmanı (2005: 106) olarak tanımlanan çevirmen öznesi, düşünme edimi sonrasında bir tercihte bulunmakta ve bu tercihler çevirmenin eyleminin amaca ulaşmasına aracı olmaktadır. Dolayısıyla amaca ulaşmada kullanılacak olan araçların düşünme yetisi ile belirlendiği açıktır. Kısacası failin, düşünme edimi sonrasında amaca ulaşmak için bir eylemde bulunması, bir tercihin sonucudur. Çeviribilimde failin çeviri eylemi sonucu ortaya çıkan şey erek metindir (Vermeer 1990: 77) ve bu metin kaynak metni kendine dayanak alan failin zihnindeki formdur. Metnin varlığı, fail nedeni gerektirir ve metin, yaratıcısı olan failin eyleyerek meydana getirdiği bir sanat eseridir.

Çeviri tarihine bakıldığında eylemde bulunan ve eylemi sonucunda bir ürün ortaya koyan çevirmenden çokta fazla söz edilmediği görülmektedir. Çevirmen geçmişte sadece kaynak metnin sözcüklerini ve cümlelerini sözlük yardımıyla bir dilden öbür dile aktaran olarak görülmüş ve eylemi eşdeğerlik denen ilkeyle sınırlandırılmıştır. Yetmişli yılların sonu seksenli yılların başlarında yapılan çalışmalar ile çeviride işlevsel ve betimleyici yaklaşımların, yani erek odaklı yaklaşımların öne çıkmasıyla çevirmen öznesi ve özne algısı öne çıkmış ve çeviri araştırmalarında fail neden özel araştırma 
alanı olagelmiştir. Bireyin işin içinde olması bireyin yorumunu, sosyolojik konumunu, kültürünü, vb. etkenleri beraberinde getirdiğinden, çevirmen öznesi bağlamında eylemde bulunan fail, maddeye form verirken bu etkenlerden bağımsız hareket edemeyecektir. Çeviribilimde fail nedene her ne kadar çevirmen öznesi karşılık gelse de aslında fail nedenlerin çokluğundan bahsetmek mümkün görünmektedir. Kaynak metin yazarı, kaynak metin alıcısı; çevirmen ve(ya) işveren, erek metin alıcısı olmak üzere toplam dört failin çeviriye etkisi ilgili faillerin imkân ve durumu çerçevesinden öte gidemeyecektir. Her biri ayrı düşünce gücüne sahip olan tüm bu failler, çeviri sürecinde farklı rollere sahiptir. Çeviribilim çerçevesinde faillerin çokluğunu;

1) kaynak metin yazarı ve çevirmen (ve/veya işveren)

2) kaynak metin alıcıs1 ve erek metin alıcıs1

şeklinde ikiye ayırmak mümkündür. Bu ayrımda ilk grup bir sanat eseri yaratma çabasındayken, ikinci grup, yaratılan bu sanat eseri karşısında tavır alandır. İlk grupta yer alan failleri de kendi arasında ikiye ayırdığımızda (1) kaynak metin yazarının fail olarak rolünün ve (2) çevirmenin kaynak metni erek dil ve kültürde yapılandırması bakımından fail olarak rolünün aslında çeviride iki temel rol olduğu görülür. Çeviribilim çerçevesinde fail nedenin kaynak dünyadaki temsilcisi olan kaynak metin yazarı kaynak metni üreten, kaynak metnin hangi durum ve şartlar altında oluştuğunu bilen olması bakımından mutlak anlamda maddeye sahip olan fail iken, Nord'un deyimiyle kaynak metnin gerçek alıcısı olan çevirmen (2003: 5) kaynak metne kullanma anlamında sahip olan ve erek metnin hangi durum ve şartlar altında oluşacağını bilen faildir. Pratik ve teorik akla sahip olan bu failler, bir insan eseri olan kaynak metin ve erek metinde etkindirler ve eylemde bulunan olarak eylemin kime, ne ile, niçin, nasıl yapıldığını bilirler. Her bir nesne, her bir zihin durumu, her bir eylem bir amaç tasarımı gerektirir ve zihinsel bir tasarımın yön verdiği bir eylem sonucunda meydana gelen çeviri eser, bir amaç güdülerek meydana getirilmiş olmasının yanı sıra amacı kendi içinde de taşımaktadır. Gerek kaynak metnin gerekse de erek metnin yaratımı her zaman için bu şekilde tezahür eder. Sanat ürünlerinde amacın müdahalesinin söz konusu olması dolayısıyla (Altuğ 2007: 176f) çevirinin de bir sanat eseri olması, bu etkinlikte amacın üstünlüğünü öne çıkarmaktadır. Amaç ise bir faili gerekli kıldığından sanat bir bakımdan failin duygularının dışavurumudur. Kant'a göre doğa eseri dışında yer alan her şey bir sanat eseri ve dehanın bir ürünüdür (Kant 2011). Kant'1n bu izahı çerçevesinde kaynak metin yazarı ve çevirmen birer sanatkâr, dolaysıyla dehadır. Kaynak metin ve çeviri metin ise dehanın ürünü olan bir sanat eseridir, yani çeviri, bir insan eseri olarak, sanatsal bir eylem, amaçlı yürütülen bir faaliyet sonucunda oluşur.

Yukarıda da belirtildiği gibi deha pratik ve teorik akla sahiptir ve bu durum her iki akıl arasında bir bağ olmasını gerekli kılar. Pratik akıl eylemde bulunan akıl iken, onu eylemde bulunmaya yönlendiren ise teorik akıl, daha da derine inildiğinde teorik akıldaki erektir (Ceylan 1993: 50). Teorik akıldaki erek insanı bir amaca yönlendiren düşünce olması bakımından, bir insan yapıp etmesi olan sanat durumunda kendini özellikle belli eder ve bir pratiğin ya da bir sürecin varacağı nihaî hedef anlamına gelir. Çınar, insanın eylemlerini pratik akıl bünyesinde barındırdığını, teorik akıl yürütmenin 
faile bir telos, yani amaç verirken, pratik akıl yürütmenin faili belirli yer ve zamanda doğru bir şekilde eylemde bulunmasını sağladığını belirtir (2007: 182). Nitekim insan, teorik aklındaki erek vasıtasıyla pratik aklı harekete geçirir ve nihayetinde bir eylemde bulunur. Eylemin temel özelliği ise daima bir amaç doğrultusunda belli bir hedefe yönelik olmasıdır. Eylemlerin bir amacın sonucu olarak gerçekleşmesi, amacın varlığının eylemden önce olduğunun bir göstergesidir. Eylem özellikle günümüz işlevsel çeviribilim kuramlarında genellikle uzman çevirmenin eylemi olarak nazarı dikkate alınmaktadır (Vermeer 1990: 73,76). Fakat burada çevirmen erek metni yapılandırmak üzere eylemde bulunurken kaynak metin yazarı kadar özgür değildir. Kaynak metin yazarı özellikle edebi metin bağlamında düşünüldüğünde metin üretiminde bir görev ve sorumluluk yerine getirmek için eylemde bulunmak gibi bir sorumluluk içinde değilken çevirmen bir görev ve sorumluluktan dolayı bir eylemde bulunur. Eylem bir özne tarafından, bir dayanak tarafından gerçekleştirildiğinden, eylemin yüklendiği bir özne olmalıdır ve bu bakımdan çeviri kendi başına gerçekleşen bir eylem değil, çeviri bir çevirmen eylemidir. Çevirmen bu eylemini erek metin alıcısı için kaynak metindeki bilgi sunumunu erek metinde bilgi sunumu şeklinde vererek gerçekleştirmektedir (Reiss/ Vermeer 1984).

Fail neden olmak bakımından çeviri eylemini bizzat eyleyen çevirmen, bilen özne olarak bilinen nesne olan erek metni oluşturmak için, kaynak metni alımlayan özne olmak bakımından (Nord 2003: 34) aktif olarak kaynak metnin kendisiyle, kaynak metin yazarına karşı sorumlu olması bakımından (Nord 2003: 32) pasif olarak ise özne olan kaynak metnin yazarıyla iş birliği içinde olmalıdır. Erek metnin meydana gelmesi, kaynak metnin varlığından ötürüdür ve erek metin kaynak metin ile zorunlu bir oluşsal bağıntıya sahiptir. Kaynak metin, etkin öznesi olan yazarından ayrı ve kendinde olduğu şekli itibariyle durağan bir metindir. Muharrem Tosun'un Çeviri Eleştirisi Kuramı (2013) adlı kitabında da belirttiği gibi çeviri eylemi, çevirmenin bir metni durağan bir durumdan etken bir duruma getiren bir eylemdir ve bu metni erek dünyada görünür ve bilinir kılacak olan önce çevirmenin bilgisi, sonra erek alıcının ilgisidir. Kaynak ve erek metnin ele alındığı koşullar hiçbir zaman aynı olamamakla beraber her iki metni üreten failler eylemlerini kime, ne ile, niçin yaptığını bilir. Kaynak metinden hareket ederek ona erek metin formunu veren çevirmen failinin, madde izin verdiği çerçevede ona form verebildiği düşünüldüğünde erek metne yön veren kaynak metin failinin kendisi midir, pratik aklı harekete geçirerek teorik akıldaki erek burada kimindir, çevirmen failinin mi, yoksa kaynak metin failinin mi? soruları ucu açık sorulardır. Son tahlilde şu sorunun da sorulması mümkündür; çevirmen failinin ereği kaynak metin failinin ereğinden ne denli bağımsız olabilir veya bu mümkün müdür? Şimdiye dek maddeye erek metin formunu verenin çevirmen failinin olduğu vurgulanmakla beraber, çeviride kaynak metne erek metin formunu vermede kaynak metin failinin görünmez etkisi söz konusu mudur?

Çeviribilim çerçevesinde ikinci grupta yer alan fail nedenler, yani kaynak ve erek metin alıcıları, kaynak metin yazarı ve çevirmen olarak sınıflandırılan birinci grup fail nedenlerin ürünü olan sanat eserini kavrayanlardır. Sanat eserleri Kant'ın salt düşünmenin söz konusu olduğu düşünülür dünyası ile zaman ve mekân içindeki fenomenlerin söz konusu olduğu duyulur dünyası (Kant 2011) bağlamında 
değerlendirilmek istendiğinde hem kaynak hem de erek metnin hem duyulur hem de düşünülür dünyaya ait oldukları söylenebilir. Kaynak metin failinin düşünülür dünyasında var olup duyulur dünyasında hayat bulan kaynak metin, hem kendi alıcısının düşünülür dünyasında canlanacak, hem de çevirmen failinin düşünülür dünyasında kod değişimine uğrayarak duyulur dünyasında hayat bulacak ve bu metin erek alıcının düşünülür dünyasında yeniden canlanacaktır. $\mathrm{Bu}$ zincirlemede kaynak metin faili ve çevirmen faili arasında bilgi ve nesne (kaynak metin) açısından bir bağ kurulması söz konusuyken, kaynak ve erek metin alıcısında böyle bir bağdan söz edilmesi çok da mümkün değildir.

Kaynak metin failinin ortaya koyduğu sanat eserinin üç ayrı alıcı tarafından alımlanması söz konusudur, bunlar;

1. Kaynak metin alıcisı

2. Çevirmen

3. Erek metin alıcisı.

Her üç fail, alımlama esnasında hayal gücü ve anlama yetilerini devreye sokar. Öznenin nesneye karşı takındığı tavır, onun nesneyi algılaması ile doğru orantılıdır ve alıcının metin karşısındaki durumu, onun bir yargıda bulunmasına olanak sağlar. Özne yargılama yetisi aracılığıyla nesneye ilişkin öznel duygularını izaha çalıştığından, öznenin nesneye karşın nesnel bir yargıda bulunması söz konusu olamaz. Öznenin algısı olmaksızın bir nesneden bahsetmek imkânsızıdır ve bu nedenle çevirilerde ön planda olan, bilinen nesne dediğimiz metindir.

İşlevsel çeviri kuramlarının öne çıkardığı çevirmen faili, Aristoteles'in fail nedeni ile karşılanabilmekle beraber, çeviride fail dendiğinde sadece çevirmenin değil, iki gruptaki tüm faillerin etkin rol oynadığı söylenebilir.

\section{- Ereksel Neden ve Çeviribilim}

Aristoteles'in dört temel neden türünden birini teşkil eden ereksel nedende söz konusu olan, kendi uğruna bir şeyin olması, yani bir şeyin olmasına neden olmaktır. Bir şeyin varoluş amacının o şeyin nedeni olması, bu neden türünün sonuç odaklı olmasından ötürüdür. Yani erek, bir eylemde bulunurken varılmak istenen sona tekabül etmektedir ve bu bakımdan bir anlamda neden ve ne için sorularına verilmiş yanıt niteliğindedir. Aristoteles'in dört nedeninden biri olan ereksel nedenin çeviribilimde çevirinin amacı ile karşılanabilmesi söz konusudur. Çeviride ise amaç söz konusu olduğunda akla ilk gelen kuram H.J. Vermeer'in Skopos Kuramıdır. Kuramcı bu kuramında her eylemin bir amacı olduğundan, çevirinin de bir eylem olması hasebiyle bir amacı olduğundan bahseder (Reiss/Vermeer 1984). İnsanın belli bir amaç uğruna gerçekleştirdiği tüm eylemleri erekli eylemlerdir ve her erek bu bakımdan bir tasarımın sonucudur. Bir anlamda erek, bilinçli şekilde gerçekleştirilen eylem ile ulaşılmak istenen sondur. Bir eylemin, bir olayın nedenlerini göz önünde bulundurmak, nedenler üzerinde düşünmeye 
yönelmekle mümkündür ve temel neden türlerinden biride erektir. Dolayısıyla erek, nedensel düşünmenin bir parçasıdır.

Her eylem, her bir hareket ve bir zaman alır ve belli bir ereğe yöneliktir. Eylem veya hareket ancak kendi ereğine ulaştığında bitmiş, yani tamamlanmış olur (Ross 2002: 265). Vermeer Voraussetzungen für eine allgemeine Translationstheorie (1986) adlı eserinde çevirinin erekbilimsel, yani teleolojik olduğuna değinmiştir. Kuramcı aynı eserde erekbilimsel bakış açısına göre eylemlerin amacı olduğundan ve bu bağlamda iletişimsel olarak eylemde bulunulduğundan ve çevirinin yapıldığından bahseder. Amaç denildiğinde bir şey yapmak merkezi konumda yer alır ve ancak eğer niçin yapıldığı bilinirse çeviri yapılabilir, yani öncelikli olarak eylemlerin bir amacı olmalıdır (Vermeer 1986: 290).

Ereksel nedende söz konusu olan ereğe ulaşmadır ve ereğine ulaşmak Skopos Kuramındaki amaçlanmış bir hedefe ulaşmak ile eş tutulabilir ve bu da kuramcıların çeviride baskın unsur olarak amacı görmeleri ve

Skopos $=$ Zweck, Ziel

formülasyonunun ereksel neden ile karşılanabileceğini gösterir. Bu kurama göre çeviri, kaynak metne dayalı olarak gerçekleşen amaçlı bir eylemdir (Du 2012: 2193) ve sonuç odaklı olarak bilinen Skopos Kuramı, yine sonuç odaklı olan ereksel neden bağlamında değerlendirildiğinde; çevirilerin varoluş amacını, çevirilerin varmak istediği hedef belirlemektedir.

Çeviribilimde ereğine ulaşacak olan, kaynak metni kendine dayanak alan, erek güdümlü olan erek metindir. Bir öznenin amaçlı bir eylemi sonucunda ortaya çıkan metinlerde rastlantısallık söz konusu edilemez. $\mathrm{Bu}$ ve benzeri şekilde meydana gelmelerde bir amaç doğrultusunda meydana gelme söz konusudur. Yani özne, bir amaç doğrultusunda belli bir hedefe yönelik olarak eylemini gerçekleştirir. Eylem denilen insan etkinliğinin amaçlı bir davranış olması ve bu amacın, eylemin dışında değil niyet, hedef bağlamında eylemin içinde bulunması, eylemin hareketini başlatır. İnsana yöneltilen neden sorusu esas itibariyle bir eyleme gönderme yapmaktadır. Eylemin eylem olarak adlandırılabilmesi, onun amaçlı bir etkinlik olması ile mümkündür ve bir anlamda ereksellik amaçlı eylem demektir. Çeviribilim için bu amaçlı eylem gerek çevirmenin gerek kaynak metin yazarının ve alıcının gerekse de erek alıcının amaçlı eylemidir. Ereksellik bağlamında ereksel neden ise o takdirde amacına ulaşmış olan eylem ile ilgilidir.

İşlevsel çeviri kuramlarında çevirinin merkezinde olan erek metin, varlığa gelmeden önce amaçların saptanmasını ve çeviri sürecini, nedenler bağlamında şart koşar. Erek metinden önce var olan kaynak metin, ereksel neden bağlamında, sonradan olacak olan erek metne etkide bulunandır. Bu etki sürecinin çeviri sürecinde etkin bir payı vardır. Kaynak metin erek metne neden olan, erek metin ise kaynak metinden meydana gelendir ve bu bakımdan sonradan meydana gelen olarak erek metin, nedeni olan kaynak metinden hiçbir zaman önce meydana gelmeyecektir. Form fiil, madde kuvve ise madde-form çiftinde form kategorisini niteleyen erek metin, kaynak metne 
biçim vermiş olma anlamında kaynak metnin erek dünyada alacağ şekli ve bu nesnenin sınırını belirleyendir. Yani erek metin, kaynak metnin erek dünyada biçim almış formudur ve bu form erek metnin sınırlarını belirler. Ve var olan kaynak metinden bir erek metnin oluşması, kaynak metnin ereksel olmasından ötürüdür.

Erek sözcüğü Aristoteles’te (1) doğanın ereği ve (2) insan eyleminin ereği olmak

üzere iki şekilde karşımıza çıkar (Aristoteles 2010). Dolayısıyla hem doğa oluşumlarının hem de insanın amaçlı eyleminde temelinde bu eylemlerin erekli, yani amaçlı olması yatar. Buradan hareketle erekselci görüşün başta doğa ve insan eylemleri olmak üzere tüm eylemlerin amaçları tarafından belirlendiği görüşünü temsil ettiği söylenebilir.

Çeviribilimde de ereği (1) çevirmen öznesinin eylemi, çevirinin ne için, neye istinaden, hangi amaçla yapıldığı, yani çeviri sürecinin erekselliği ve (2) bu eylemin varacağı hedef, yani çevirinin yapıldığı yönü belirtmesi ve bu bakımdan metin, dil, kültür ve alıcıyı tanımlaması, kısacası çeviri ürününün varlık nedenini izah etmesi bakımından ikiye ayrılır. Çeviri eyleminin nedeni ve erek metnin varlık nedeni olmak bakımından erek, birinci durumda failin zihnindeki ereği nitelerken, ikinci durumda nesnenin kendisini nitelemektedir. Özellikle paradigma değişimi sonrasında öne çıkan erek odaklılık ve amaca yönelik eylemde bulunma durumu, çeviriye bütünsel açıdan erekbilimsel bir bakış açısı ile bakmayı beraberinde getirmiştir.

Erekli davranışta bulunma, insan etkinliğine özgü bir durumdur ve bilinçli bir amaç içerir. Çevirmen eylemi sonucunda ortaya çıkan ürünün tek bir izahı mümkündür, o da bu ürünün rastlantısal olarak değil bilinçli bir eylem sonucunda ortaya çıkmasıdır. Bilinçli eylem demek önceden belirlenmiş bir erek (amaç) ile davranışta bulunmak demektir. Bu bilinçli davranış sonucunda elde edilen ürün (çeviri metin) ancak ereği ile açıklanabilir. Tüm çeviri süreci boyunca varlığını sürdüren ve çeviri sürecine yön veren ereklilik durumu, istenilen sonuca ulaşıldığında son bulacaktır. Niçin sorusunun cevabının kendinde arandığı şey olan ereklilik, çevirinin niçin yapıldığını ortaya koyar. Dolayısıyla çevirmen eylemini etkileyen, amacın kendisidir.

Her türlü yapıp etmelerimiz bağlamında eylemlerimizin uğruna gerçekleştiği şeylere tekabül eden erek, bir eylemin bir olayın nedenini göz önünde bulundurmamıza olanak sağlar. Bu bakımından çevirmen öznesinin eylemi bir tasarımın, bir düşüncenin ürünü olan erekli bir eylemdir. Bu haliyle erek, davranışı yönlendiren düşünceye işaret etmekte ve eylemi etkilemektedir. Nihayetinde erekbilimin temelinde amaçli eylemde bulunma yatar. İnsanın planlayan düşüncesi ve yeteneğine bağlı olarak meydana gelen çeviri metin, bir amaç için meydana gelir ve bir hedefe ulaşmayı amaçlar.

\section{Sonuç}

Pym'in 1970'li yılların sonlarına doğru çeviride yaşanan paradigma değişimini maddi nedenden ereksel nedene olan bir kayma olarak değerlendirdiği göz önüne alındığında, onun dilbilimsel yaklaşımları maddi neden bağlamında, paradigma değişimi ile çeviride etkin olan işlevsel yaklaşımları ise ereksel neden bağlamında değerlendirdiği 
söylenebilir (2014: 157-159). Çünkü nedenlerle bilmenin en iyi bilgiyi vereceğinden yola çıkarak dört nedenin olmazsa olmazlığından bahseden Aristoteles bakış açısında bu nedenler bir arada olmalıdır ve birinin diğerine bir baskınlığı söz konusu değildir. Bu bakımdan Pym'in de bir çeviriyi elde etmek için dört nedeni gerekli görmesi, onun çeviribilme yaklaşımında her çeviride dört nedenin söz konusu olduğu görüşünü savunduğu anlamına gelmektedir. Nedenler arasında herhangi biri baskın olabilir, fakat herhangi bir neden tüm olguyu açıklamada yetersiz kalacağından her çeviride dört neden bir arada bulunmalidir.

Bilgiye ulaşma çabası neticesinde Aristoteles'in Dört Neden Kuramını ortaya koyması ve bilgiye ancak bu nedenler ile ulaşılabileceği görüşünden yola çıkarak bu çalışmada çeviribilimin temel öğeleri olan kaynak/erek metin, kaynak/erek dil, kaynak/erek kültür, kaynak metin yazarı/çevirmen, kaynak/erek alıcı gibi kavramlar sorgulanmış ve birbirleriyle olan ilişkilerinin felsefi izahı yapılmaya ve açıklanmaya çalışılmıştır. Çeviri ürünü olan metnin neliğini, erek dünya ve kaynak metin ile bağıntısını açıklayabilmek bu dört neden ile mümkündür. Varlığın bilgisine ulaşmada ve varlığı kavramada geçerli olan dört neden çeviribilim bakış açısı ile ele alıp değerlendirildiğinde, nedenlerin çevirmen, çeviri süreci, çeviri ürünü, kaynak metin, erek alıcı gibi birçok parametreyi kapsadığı ve bunların son tahlilde çeviri ürünü olan varlığın bilgisine ulaşmada bütünün birer parçası olduğu görülmektedir. Aristoteles'in Dört Neden Kuramı bağlamında yapılan sorgulama çevirinin araştırma nesnesi olan çeviri metnin doğasını belirlemek adınadır. Kaynak metin ve yazarı, çevirmen, işveren, erek dil, kültür, alıc1, zaman, ihtiyaç gibi farklı faktörlerin etkisi ile, bu ve benzeri faktörleri içine alarak belirli bir zamanda ve belirli bir yerde var olan çeviri metin, bilinen nesne olmak bakımından çoğu zaman üzerine yoğunlaşılan ve tartışılan bir nesne olmuştur. Kendisine yönelteceğimiz niçin veya neden sorularının cevabı ile kendisi hakkında bilgi edinmeye çalıştığımız çeviri metin maddi, formel, fail ve ereksel olmak üzere dört neden ile açıklanabilmektedir.

Çeviride aynı anda bir maddi neden olmak bakımından kaynak metin, bir formel neden olmak bakımından çeviri formu, bir fail neden olmak bakımından çevirmen ve bir ereksel neden olmak bakımından çevirinin amacından söz edilebilir. Nedenler arasında bir hiyerarşi söz konusu olmamakla birlikte, herhangi bir neden türü her bir çeviri durumuna göre bir önceliğe sahip olabilir, fakat dört neden bir arada bulunmadığı takdirde bir çeviriden bahsedilmeyecektir.

Maddi Neden=Kaynak Metin

Formel Neden=Erek Metin

Fail Neden $=$ Çevirmen

Ereksel Neden $=$ Çevirinin Amacı

Çevirinin nelerden meydana geldiğini ve bu nelerin birbirleriyle olan ilişkisini araştırmayı ve çevirinin doğası hakkında fikir edinmeyi amaçlayan bu çalışmada, çeviride değişen unsur olarak kaynak metnin erek metin yönünde bir değişme gösterdiği, madde olmak bakımından kaynak metnin yöneldiği bu değişimin formel neden ile 
belirlendiği ve bu iki nedenin varlıktaki değişimin iç nedenlerine tezahür ettiği görülmüştür. Kaynak metinden erek metne doğru gerçekleşen değişimde, diş nedenler ise fail ve ereksel neden olarak belirlenebilmektedir. Değişmeyi başlatan, onu gerçekleştiren olarak fail neden olmak bakımından çevirmen ve değişimin hangi amaca yönelik olduğunu belirleyen ereksel neden olmak bakımından çevirinin amacı varlıktaki değişimin bir anlamda dış nedenleridir. Dolayısıyla bir çevirinin ne olduğuna dair soru sorulduğunda çeviri üzerine bir araştırma içine girmiş olunur ve çeviri, maddesi kaynak metin, formu erek metin, faili çevirmen ve ereği çevirinin amacı olan bir etkinliktir.

Paradigma değişiminin öncüleri olan işlevsel çeviri kuramlarından Skopos Kuramının ereksel neden olarak çevirinin amacına ağırlık verdiği, Çeviri Eylemi Kuramının fail neden olarak çevirmene ağırlık verdiği söylenebilir.

\section{Kaynakça}

Altuğ, Taylan (2007): Kant Estetiği. 2.Baskı, İstanbul, Payel Yayınevi.

Aristoteles (1997): Fizik. çev. Saffet Babür, Yapı Kredi Yayınları.

Aristoteles (2010): Metafizik. çev. Ahmet Arslan, 3. Bask1, İstanbul, Sosyal Yayınlar.

Aristoteles (2011): İkinci Çözümlemeler, çev. Ali Houshiary, 2. Baskı, İstanbul, Yapı Kredi Yayınları.

Arslan, Ahmet (2007): İlkçağ Yunan Felsefesi, Aristoteles. İstanbul Bilgi Üniversitesi

Baker, Mona/ Chesterman, Andrew (2008): Ethics of Renarration-Mona Baker is Interviewed by Andrew Chesterman', Cults 1(1). 10-33.

Berk, Özlem (2005): Kuramlar Işı̆̆ında Açıklamalı Çeviribilim Terimcesi, İstanbul, Multilingual.

Büyüközkara, Ender (2010): Aristoteles 'te Ahlakın Temel Bilgisi, Sakarya Üniversitesi, Yayınlanmamış Yüksek Lisans Tezi.

Ceylan, Yasin (1993): Kavram Üzerine, Felsefe Dünyası, Sayı 9, Ekim, Ankara. 46-50.

Chesterman, Andrew (2008): On explanation, içinde Beyond Descriptive Translation Studies, Anthony Pym, Miriam Schlesinger, Daniel Simenoi (ed), Amsterdam-Philadelphia, John Benjamins Publishing. 363-379.

Chesterman, Andrew (2010): "Skopos Theory: a Retrospective Assessment", Perspektiven auf Kommunikation. Festschrift für Liisa Tiittula zum 60. Geburtstag, W. Kallmeyer u.a. (Hrsg), Berlin: SAXA Verlag. 209-225.

Çınar, Aliye (2007): Aristoteles'in Nikomakhos'a Etik'inde Pratik Hikmet Kavramı ve Günümüz Açısından Önemi, Uludă̆ Üniversitesi, İlahiyat Fakültesi Dergisi, Bursa, Cilt:16, Say1:1. 171-192.

Delisle, J., Lee Jahnke, H., Cormier, C.M. (1999): Terminologie der Übersetzung, Amsterdam, John Benjamins Publishing Company.

Du, Xiaoyan (2012): A Brief Introduction of Skopos Theory", Theory and Practice in Language Studies. Vol. 2, No. 10, October, Manufacture in Finland, Academy Publisher. 2189-2193.

Kant, Immanuel (2011): Yargı Yetisinin Eleştirisi. çev. Aziz Yardımlı, 2. Baskı, İstanbul, İdea Yayınevi.

Nord, Christiane (2003): Textanalyse und Übersetzen, Tübingen, Julius Gross Verlag.

Nord, Christiane (2011): Funktionsgerechtigkeit und Loyalität, Berlin, Frank \& Time. 
Özcan, Muttalip (2011): Aristoteles Felsefesi: Temel Kavramlar ve Görüşler. 1.Baskı Ankara, Bilgesu Yayıncilik.

Pym, Anthony (2012): On Translator Ethics, Amsterdam/Philadelphia, John Benjamins Publishing Company.

Pym, Anthony (2014): Method in Translations History. London, Routledge.

Reiss, K./ Vermeer, H.J. (1984): Grundlegung einer allgemeinen Translationstheorie, Tübingen, Max Niemeyer Verlag.

Ross, David (2002): Aristoteles, çev. Ahmet Arslan, Kabalcı Yayınları.

Salevsky, Heidemarie (2002): Translationswissenschaft, Frankfurt, Peter Lang.

Tosun, Muharrem (2013): Çeviri Eleştirisi Kuramı, Aylak Adam, İstanbul.

Vermeer, Hans J. (1983): Aufsätze zur Translationstheorie. Heidelberg

Vermeer, Hans J. (1986): Voraussetzungen für eine Translationstheorie. Heidelberg.

Vermeer, Hans J. (1990): Skopos und Translationsauftrag, Heidelberg, 